\title{
AUDIT OF PUBLIC RESEARCH INSTITUTIONS
}

\author{
[Audit veřejných výzkumných institucí]
}

\author{
Marek Jošt ${ }^{1}$ \\ ${ }^{1}$ Vysoká škola ekonomická v Praze, Fakulta financí a účetnictví, nám. Winstona Churchilla 4,130 67 Praha 3 \\ Email:marek.jost@vse.cz
}

\begin{abstract}
The article analyzes selected factors of the audit of the financial statements of public research institutions. Specifically, it concerns the structure of auditors, the concentration of audit engagements in small number of auditors, the rotation of auditors and the disclosure of the remuneration for the audit company in the notes to the financial statements. The article mentions similar researches conducted in different types of non-profit organizations and the conclusions are then compared. The auditors of the financial statements of public research institutions are usually audit companies rather than the statutory auditors. Public research institutions, as well as other nonprofit organizations, use the particular auditor for a long period of time. It appears, in the case of public research institutions, that more and more audit engagements are provided by one audit company. A significant number of public research institutions do not disclose the renumeration for the audit company in the notes to the financial statements.
\end{abstract}

Keywords: accounting, audit, public research institution, transparency.

JEL classification: M41, M42

Received: 22.5.2020; Reviewed: 27.5.2020; 15.6.2020; Accepted: 9.9.2020

\section{Úvod}

Veřejná výzkumná instituce je definována v zákoně č. 341/2005 Sb., o veřejných výzkumných institucích $\mathrm{v} \S 2$ odst. 1 jako: „Právnická osoba, jejímž hlavním předmětem činnosti je výzkum, vč. zajišt’ování infrastruktury výzkumu, vymezený zákonem o podpoře výzkumu, vývoje a inovací. Veřejná výzkumná instituce svou hlavní činností zajištuje výzkum podporovaný zejména $\mathrm{z}$ veřejných prostředků $\mathrm{v}$ souladu s podmínkami pro poskytování veřejné podpory stanovenými právem Evropských společenství.“ Stejný zákon pak upravuje zřízení a vznik, zrušení a zánik těchto organizací, rejstřík, do něhož se zapisují, působnost zrrizovatele, orgány (ředitel, rada instituce a dozorčí rada), vnitřní prredpisy, hospodaření (rozpočet, fondy, majetek), účetnictví a výroční zprávu apod.

Veřejné výzkumné instituce sestavují vyrovnaný rozpočet na kalendářní rok a střednědobý výhled rozpočtu na min. 2 následující roky a zveřejňují je do 30 dnů ode dne schválení radou instituce. Tento rozpočet zachycuje náklady a výnosy související s hlavní činností, další činností (tj. činnost prováděná na základě požadavků příslušných organizačních složek státu nebo územních samosprávných celků ve veřejném zájmu a podporovaná $z$ veřejných prostř̌edků) a jinou činností (tj. činnost hospodářská prováděná za účelem dosažení zisku podnikání). Jak vyplývá se zákona o veřejných výzkumných institucích, z výročních zpráv a účetních závěrek, specifickým zdrojem financování jsou u těchto organizací podpory výzkumné organizace na základě dosažených výsledků nebo projektů výzkumu, vývoje a inovací z veřejných prostředků podle zvláštního právního předpisu. Často jsou tyto výzkumné organizace financovány z prostředků Grantové agentury ČR, Technologické agentury ČR a jiných veřejných tuzemských zdrojů či zdrojů Evropské unie formou institucionální nebo účelové podpory. 
Veřejné výzkumné instituce vytváří podle $§ 23$ zákona o veřejných výzkumných institucích rezervní fond, fond reprodukce majetku, fond účelově určených prostředků a sociální fond.

O způsobilých nákladech projektů výzkumu, vývoje a inovací vedou instituce oddělenou evidenci a $\mathrm{v}$ rámci ní sledují náklady hrazené $\mathrm{z}$ institucionální nebo účelové podpory výzkumu, vývoje a inovací z veřejných prostř̌edků podle zvláštních právních předpisů.

Veřejné výzkumné instituce se řadí mezi tzv. nestátní neziskové organizace, tedy organizace, které nejsou zakládány primárně za účelem dosahování zisku, ale k poskytování veřejně prospěšných služeb v různých podobách. V současnosti mezi nejvíce uznávanou definici neziskových organizací patří pravděpodobně ta od autorské dvojice sociologů Salamona a Anheiera (1996). Podle ní charakterizuje neziskové organizace: organizovanost, soukromý charakter a nezávislost na státu, nerozdělování zisku, samosprávnost a dobrovolnost.

V posledních letech se začíná stále více hovořit o tzv. transparentnosti nejen na úrovni hospodaření státní správy, podnikatelských subjektů, ale také v souvislosti s nestátními neziskovými organizacemi, které jsou př́ijemci značných prostředků z veřejných zdrojů a od dárců. Tito mají zájem na tom, aby s jimi poskytnutými prostředky bylo naloženo hospodárně a v souladu s př́ślušnými smlouvami.

Definování pojmu transparentnost se v minulosti věnovalo již mnoho českých i zahraničních autorů a shodují se na tom, že souvisí se stavem občanské společnosti dané země. Např. Putnam (1993) poukazuje na to, že ekonomická prosperita dané země a rozvoj občanské společnosti spolu úzce souvisí. Autor porovnával vybrané regiony Itálie a dospěl ve své studii k následujícímu závěru: regiony s nerozvinutou občanskou společností vykazují nižší ekonomickou výkonnost, ale i větší sklony ke korupci a zneužívání politické protekce.

Pospíšil (2006) zmiňuje, že v úvahách o transparentnosti se kombinuje princip „,accountability“ (odpovědnost) a „transparency“ (průhlednost), přičemž podle tohoto autora je pojem ,transparency“ mnohem širší.

Dle Browna a Ruhla (2003) či Šedivého a Medlíkové (2011) transparentnost ukládá neziskové organizaci závazek pravidelně dokazovat, že používá své zdroje přiměřeně a nezneužívá svých zvláštních výhod k provozování aktivit, které by byly v rozporu s jejím statutem.

Za současné problémy spojené s transparentností tuzemských neziskových organizací lze dle Bachmanna (2012) považovat nezveřejňování nebo neexistenci poslání, nedostupnost základních organizačních dokumentů, konflikt zájmu mezi správní a výkonnou mocí, podceňování funkce kontrolních orgánů a nepřítomnost auditu.

Důvody, proč jsou některé organizace dobrovolně transparentní, se zabývali autoři Behn, DeVries a Lin (2010). Ti se změřili na to, proč některé neziskové organizace dobrovolně poskytují auditované finanční výkazy ke kontrole z důvodu vyšší transparentnosti, zatímco jiné ne. Autoři výzkumu si vyžádali auditované výkazy od 300 největších neziskových organizací v USA, přičemž zveřejnění těchto výkazů nebylo pro tyto organizace povinné. Z výsledků výzkumu vyplynulo, že auditované finanční výkazy poskytly nejčastěji organizace s vyššími ztrátami, s vyšším podílem dárců, certifikované jako organizace NTEE (The National Taxonomy of Exempt Entities; oblast vysokého školství) a s vyšším podílem spotřebovaných výdajů. 
Transparentnost lze definovat jako ochotu a schopnost naplňovat požadavky, které jsou na neziskové organizace kladeny legislativními či jinými předpisy (př́ip. smlouvami) nebo jinými subjekty skrze zveřejňování volně dostupných informací. Transparentnost lze zvyšovat zveřejňováním informací nad rámec legislativně či smluvně definovaných požadavků (Jošt 2017).

Neziskové organizace poskytují informace dárcům a celé široké veřejnosti o realizovaných činnostech a svém hospodaření obvykle prostřednictvím výročních zpráv, účetních závěrek, webových stránek apod.

Je zřejmé, že ke zvýšení transparentnosti může bezesporu přispět i ověření účetní závěrky nezávislým auditorem, jehož cílem je podle mezinárodního auditorského standardu ISA 200 Obecné cíle nezávislého auditora a provádění auditu v souladu s mezinárodními auditorskými standardy (účinný pro účetní závěrky sestavené za období končící 15. prosince 2009 nebo po tomto datu), umožnit auditorovi vyjádřit názor, zda je účetní závěrka sestavena ve všech významných ohledech v souladu s př́śslušným rámcem účetního výkaznictví. Prostředkem tohoto sdělení je výrok auditora obsažený ve zprávě nezávislého auditora $\mathrm{k}$ účetní závěrce. Tato informace může být důležitá pro uživatele účetních závěrek, resp. stávající a potenciální dárce a širokou veřejnost při rozhodování se o tom, zda dané neziskové organizaci poskytnou peněžní prostředky. Audit by měl v konečném důsledku zvýšit důvěryhodnost předkládaných účetních výkazů.

\section{Stanovení hypotéz}

V současné době nabývá audit účetní závěrky nestátních neziskových organizací na významu, což je patrné na akademické půdě i v auditorské profesi. Komora auditorů České republiky jako samosprávná profesní organizace zř́zená zákonem za účelem správy auditorské profese v ČR vydala v posledním čísle 10/2019 časopisu Auditor Metodickou pomůcku k poskytování auditorských služeb u nestátních nevýdělečných organizací dle stavu legislativy k 30. listopadu 2019. Jejím cílem je poskytnout auditorům metodickou pomoc při provádění povinného auditu vybraných nestátních nevýdělečných organizací. Metodická pomůcka upravuje také veřejné výzkumné instituce a v části Zaměření auditu - specifická rizika (rizika chápejme na úrovni auditu účetní závěrky) zmiňuje, na co by si měl dát auditor pozor, pokud ověřuje účetní závěrku těchto organizací. Celková významnost (materialita) se stanoví podle auditorského standardu ISA 320 Významnost (materialita) při plánování a provádění auditu obvykle jako procento celkových aktiv nebo celkových výnosů. Rizikovou oblastí je obecně dodržování právních předpisů, jelikož z nedodržení předpisů mohou plynout sankce, čímž může být ohrožen předpoklad nepřetržitého trvání, tak jak jej upravuje mezinárodní auditorský standard ISA 570 Nepřetržité trvání podniku. Jde zejména o dodržení pravidel pro provádění činnosti hlavní, další či jiné, sestavení rozpočtu, schvalování a dodržení vnitřních předpisů, tvorbu a čerpání fondů v souladu s vnitřním předpisem nebo dodržení pravidel pro nakládání s majetkem. Rizikovou oblastí je většinou dlouhodobý majetek, u něhož je nutné ověřit dodržení podmínek pro nakládání s ním, správnost zařazení, vyřazení i odpisování v souladu s životností daného aktiva.

Na akademické půdě v posledních letech vznikly vědecké články týkající se auditu účetní závěrky vybraných právních forem nestátních neziskových organizací, konkrétně nadací, politických stran a politických hnutí působících na území České republiky. V nich obsažené závěry slouží jak východisko pro tento článek a zejména pro stanovení hypotéz a pro porovnání zjištěných závěrů. Účetní závěrka (řádná, mimořádná i konsolidovaná) nadací podléhá ověření auditorem podle $\S 341$ odst. 1 a 2 zákona č. 89/2012 Sb., občanský zákoník, 
pokud nadační kapitál nebo obrat dosáhl v uplynulém účetním období částky 5 mil. Kč, nebo pokud se podle dané účetní závěrky rozhoduje o přeměně nadace či o snížení/zvýšení nadačního kapitálu (před účinností občanského zákoníku povinnost auditu platila pro nadace vždy bez ohledu na limity podle zákona č. 227/1997 Sb., o nadacích a nadačních fondech). Auditora určuje dozorčí rada (je-li zrrízena, jinak revizor) podle $\S 17$ odst. 2 zákona o auditorech č. 93/2009 Sb. Účetní závěrka politických stran a hnutí podléhá ověření auditorem vždy, a to podle $\S 17$ odst. 9 zákona č. 424/1991 Sb., o sdružování v politických stranách a v politických hnutích. Auditora určí statutární orgán strany nebo hnutí, přičemž téhož auditora lze určit opakovaně nejvýše 5 po sobě následujících kalendářních let. Lhůta 5 let se počítá poprvé od 1. ledna 2017. Navíc odst. 10 stejného zákona uvádí: „Účetní závěrka obchodní korporace založené stranou nebo hnutím nebo obchodní korporace, na níž se strana nebo hnutí účastní jako společník nebo člen, musí být ověřena auditorem podle zákona o auditorech. Téhož auditora pro ověření účetní závěrky podle věty první lze určit nejvýše 5 po sobě následujících kalendářních let.“ Dalším specifikem politických stran a hnutí je, že zpráva auditora musí obsahovat výrok bez výhrad. Tyto požadavky se u žádné jiné neziskové organizace nevyskytují.

Jošt (2016) se zabýval transparentností hospodaření př́jemců př́íspěvků z Nadačního investičního fondu (dále také „NIF“) za roky 2009 až 2013. Konkrétně šlo o 73 nadací a 1 nadační fond - př́ijemce, kteř́i obdrželi prostředky z NIF.

Autor ověřoval na úrovni auditu účetní závěrky platnost dvou hypotéz:

Hypotéza 1: Menší nadace využívají při ověřování účetní závěrky a výroční zprávy služeb auditorů OSVČ (osob samostatně výdělečně činných) z důvodů nižších cen a větší naopak spolupracují s auditorskými společnostmi kvůli jejich prestiži.

Hypotéza 2: Nízký počet nadací a nadačních fondů zveřejňuje odměnu za audit.

Hypotéza 1 nebyla potvrzena, jelikož kolem $60 \%$ nadací spolupracovalo ve sledovaném období s ostatními auditorskými společnostmi a zhruba $23 \%$ s auditory OSVČ. Zhruba $7 \%$ připadlo na auditorské společnosti z tzv. ,,velké čtyřky“. Zbylé nadace informaci nezveřejnily.

Hypotéza 2 byla potvrzena, jelikož jak autor uvádí, takřka ve všech účetních závěrkách a výročních zprávách se tato informace nevyskytuje.

Obdobný výzkum prováděl Jošt (2016) na statistickém souboru 100 nadací za období let 2009 až 2013. Konkrétně ověřoval platnost těchto hypotéz:

Hypotéza 1: Existuje vysoký podíl nadací, které nezveřejňují zprávu auditora.

Hypotéza 2: Vysoký podíl sledovaného vzorku nadací využívá služeb auditora OSVČ (osoby samostatně výdělečně činné) s ohledem na nižší ceny za provedený audit.

Hypotéza 3: Značný podíl sledovaného vzorku nadací nemění auditora a využívá v delším období služeb stejného auditora.

Hypotéza 4: Vysoký podíl nadací sledovaného vzorku nezveřejňuje odměnu za provedený audit.

Hypotéza 5: Výrok bez výhrad se objevuje ve zprávách auditora u značné části nadací.

Hypotéza 1 byla potvrzena pouze $\mathrm{v}$ posledním sledovaném roce. $Z$ výsledků vyplývá, že zprávu auditora zveřejnilo ve sledovaném období zhruba $84 \%$ nadací, avšak v posledním sledovaném roce 2013 to bylo už jen pouhých 69 \%. Je patrné, že ke konci platnosti zákona o nadacích a nadačních fondech došlo $\mathrm{v}$ této oblasti $\mathrm{k}$ výraznému zhoršení a nadace se staly méně transparentními. 
Auditoři OSVČ zaujímali v jednotlivých letech nízký a stále se zmenšující podíl. Hypotéza 2 tedy nebyla potvrzena. Auditorské společnosti z ,velké čtyřky“ prováděly audit u zhruba $8 \%$ - 12 \% nadací. Naopak důležitou roli hrají při auditu nadací ostatní auditorské společnosti provádějící audit u téměř poloviny českých nadací.

$\mathrm{V}$ převážné části výročních zpráv a příloh $\mathrm{k}$ účetním závěrkám českých nadací uživatelé nenaleznou informaci o odměně za provedený audit. Toto zjištění přispělo k potvrzení hypotézy 4.

Všem nadacím, které zveřejnily výrok auditora, at' už př́mo zveřejněním zprávy auditora nebo uvedením výroku v př́loze v účetní závěrce, byl udělen výrok bez výhrad, což potvrzuje hypotézu 5. Pouze jedna nadace obdržela v roce 2012 výrok s výhradou.

Jošt (2018) se ve svém př́íspěvku zaměřuje především na to, jaké je rozložení auditorských zakázek týkajících se ověření účetní závěrky politických stran a politických hnutí za rok 2017 mezi auditory, jaká je koncentrace zakázek v rámci jednotlivých auditorů, zda auditor udělil ve své zprávě k účetní závěrce politickým stranám a hnutím výrok bez výhrad a zda je zveřejňována $\mathrm{v}$ prŕíloze $\mathrm{v}$ účetní závěrce odměna auditora za provedený audit, tak jak to požaduje vyhláška č. 504/2002 Sb.

Autor stanovil dvě hypotézy:

Hypotéza 1: Auditorské zakázky zaměřené na ověření účetní závěrky politických stran a politických hnutí jsou rozloženy primárně mezi auditory osoby samostatně výdělečně činné (OSVČ) a ostatní auditorské společnosti.

Hypotéza 2: Míra koncentrace auditních zakázek týkajících se ověření roční účetní závěrky politických stran a hnutí se pohybuje z hlediska jednotlivých auditorů a auditorských společností na poměrně vysoké úrovni.

Veškerá data se vztahují k 31. květnu 2018 a vycházejí z výročních finančních zpráv a účetních závěrek sestavených za rok 2017 aktivních politických stran a hnutí zveřejněných na webových stránkách Úřadu pro dohled nad hospodařením politických stran a politických hnutí. Statistický soubor zahrnuje 154 stran a hnutí.

Hypotéza 1 byla potvrzena, jelikož $98 \%$ stran a hnutí zkoumaného statistického souboru uzavírá smlouvu o provedení auditu s auditory osobami samostatně výdělečně činnými (OSVČ) a ostatními auditorskými společnostmi nepatřícími do skupiny tzv. „,velké čtyřky“ (angl. Big Four). Pouze politické hnutí ANO 2011 využilo služeb auditorské společnosti Ernst \& Young Audit, s. r. o.

Celkem 73 auditorů a auditorských společností (tj. 47,40 \%) ověřovalo účetní závěrku za rok 2017 pouze jedné politické strany nebo jednoho politického hnutí. V ostatních př́padech auditoři a auditorské společnosti ověřovali za rok 2017 účetní závěrku dvou až pěti stran či hnutí (tj. 52,60\%). Pouze jeden auditor osoba samostatně výdělečně činná ověřoval účetní závěrku za rok 2017 u 5 politických hnutí. Hypotéza 2 tak byla potvrzena.

Výrok bez výhrad byl udělen 153 stranám a hnutím (tj. 99,35 \%).

Za rok 2017 nezveřejnilo v prŕloze v účetní závěrce odměnu auditora 129 stran a hnutí (tj. 83,77\%). 
Ve sledovaném roce 2017 vykázalo 26 stran a hnutí (17\%) zápornou výši vlastních zdrojů, což je skutečnost, která může v budoucnu ohrozit předpoklad „going concern“.

Citované vědecké články vycházejí z veřejně dostupných účetních závěrek a výročních zpráv vybraných neziskových organizací. Jednotlivé dílčí závěry vypovídají o tom, kolik organizací zahrnutých do statistického souboru vyhovuje sledované veličině (absolutní počet), př́p. jaký je podíl těchto organizací na celkovém počtu subjektů zahrnutých do statistického souboru (relativní počet).

K podobným zjištěním, stejně jako zmíněné výzkumy, dospěla i Lérová (2015), která ve svém článku uvádí auditory ověřující účetní závěrky sedmi politických stran a hnutí tehdy zastoupených v Poslanecké sněmovně Parlamentu České republiky a dalších dvanácti vybraných stran a hnutí za roky 2013 a 2014. Pouze v př́ípadě politického hnutí ANO 2011 ověřovala jeho účetní závěrku v obou letech společnost $\mathrm{z}$,velké čtyřky“ Ernst \& Young. V roce 2013 ověřovali auditoři OSVČ účetní závěrku 6 politických stran a hnutí a na ostatní auditorské společnosti připadlo zbylých 12 auditních zakázek. V roce 2014 pak připadlo na auditory OSVČ 7 auditních zakázek a na ostatní auditorské společnosti 11 zakázek. Ke změně auditora mezi roky 2013 a 2014 došlo pouze u třech subjektů, v prvním př́ípadě formou přechodu od ostatní auditorské společnosti $\mathrm{k}$ auditorovi OSVČ a ve zbylých dvou př́padech přechodem mezi ostatními auditorskými společnostmi.

Závěry zmíněných výzkumů týkajících se jiných typů neziskových organizací posloužily při stanovení hypotéz ověřovaných $\mathrm{v}$ tomto článku. Následně jsou porovnány se závěry analýzy provedené $\mathrm{v}$ tomto článku.

\section{Vymezení statistického souboru}

Veškerá data použitá pro analýzu platí dle stavu k 20. březnu 2020 a jsou převzata z rejstř́ku veřejných výzkumných institucí vedeného Ministerstvem školství, mládeže a tělovýchovy ČR. K tomuto dni bylo v rejstř́íku uvedeno 79 institucí, z nichž 2 nesly označení jako zaniklé nebo v likvidaci. Statistický soubor použitý pro analýzy zahrnuje všechny aktivní instituce. Jde tedy o úplný statistický soubor. Analýza je provedena za posledních pět let, tedy za roky 2014 až 2018, jelikož v době psaní článku nebyla ještě k dispozici data za rok 2019. Data uvedená vjednotlivých tabulkách představují absolutní počty subjektů vyhovujících sledované veličině, př́íp. relativní počty vyjádřené jako podíl subjektů vyhovujících sledované veličině na celkovém počtu subjektů zahrnutých do analýzy.

Z celkového počtu 77 institucí bylo zapsáno do rejstř́íku 71 z nich v roce 2007, 1 instituce byla zapsána $v$ roce 2008, 2 instituce $v$ roce 2011, 1 instituce $v$ roce 2016 a 2 instituce $v$ roce 2019. Převážná část organizací má v rejstř́iku uvedené datum zápisu 1. 1. 2007, což souvisí s § 31 odst. 1 zákona o veřejných výzkumných institucích, jenž uvádí, že státní příspěvkové organizace, které jsou uvedeny v př́loze č. 1 k tomuto zákonu, se dnem 1. ledna 2007 stávají veřejnými výzkumnými institucemi a Ministerstvo školství, mládeže a tělovýchovy zapíše tyto do rejstř́iku. 
Níže uvedená Tabulka 1 zachycuje působnost institucí podle jejich sídla. Z ní plyne, že drtivá většina institucí působí na území Hlavního města Prahy, následovaného kraji Jihomoravským a Středočeským.

Tabulka 1: Veřejné výzkumné instituce podle sídla

\begin{tabular}{|c|c|c|}
\hline Kraj & Počet absolutní & Počet relativní \\
\hline Jihočeský & 1 & $1 \%$ \\
\hline Jihomoravský & 11 & $14 \%$ \\
\hline Karlovarský & 1 & $1 \%$ \\
\hline Královéhradecký & 1 & $1 \%$ \\
\hline Liberecký & 1 & $1 \%$ \\
\hline Moravskoslezský & 1 & $1 \%$ \\
\hline Hlavní město Praha & 49 & $65 \%$ \\
\hline Stř́edočeský & 10 & $13 \%$ \\
\hline Ústecký & 2 & $3 \%$ \\
\hline Celkem & $\mathbf{7 7}$ & $\mathbf{1 0 0} \%$ \\
\hline
\end{tabular}

Zdroj: Vlastní zpracování na základě údajů zveřejněných v rejstř́íku VVI k 20. březnu 2020.

Z hlediska zřizovatele připadá nejvíce institucí na Akademii věd ČR a zbylé instituce zřizují ministerstva, kraje, města či obce (viz Tabulka 2). Veřejné výzkumné instituce mohou dle příslušného zákona zřizovat Česká republika nebo územní samosprávné celky. Jménem ČR plní funkci zřizovatele ministerstvo, jiný ústřední orgán státní správy nebo Akademie věd v postavení organizačních složek ČR.

Tabulka 2: Veřejné výzkumné instituce podle zřizovatele

\begin{tabular}{|c|c|c|}
\hline Zřizovatel & Počet absolutní & Počet relativní \\
\hline Akademie věd ČR & 54 & $71 \%$ \\
\hline Český úřad zeměměřický a katastrální & 1 & $3 \%$ \\
\hline Státní úřad pro jadernou bezpečnost & 2 & $1 \%$ \\
\hline Jihomoravský kraj & 1 & $1 \%$ \\
\hline Karlovarský kraj & 1 & $1 \%$ \\
\hline Královéhradecký kraj & 1 & $1 \%$ \\
\hline Ministerstvo dopravy ČR & 1 & $3 \%$ \\
\hline Ministerstvo práce a sociálních věcí ČR & 2 & $1 \%$ \\
\hline Ministerstvo školství, mládeže a tělovýchovy ČR & 1 & $1 \%$ \\
\hline Ministerstvo zahraničních věcí ČR & 1 & $10 \%$ \\
\hline Ministerstvo zemědělství ČR & 7 & $3 \%$ \\
\hline Ministerstvo životního prostředí ČR & 2 & $1 \%$ \\
\hline Obec Mšené Lázně & 1 & $1 \%$ \\
\hline Statutární město Liberec & 1 & $1 \%$ \\
\hline Ústecký kraj & 1 & $\mathbf{1 0 0} \%$ \\
\hline Celkem & $\mathbf{7 7}$ & \\
\hline
\end{tabular}

Zdroj: Vlastní zpracování na základě údajů zveřejněných v rejstříku VVI k 20. březnu 2020.

Veřejné výzkumné instituce spravovaly na konci roku 2018 aktiva ve výši 48 mld. Kč. Ve sledovaném období let 2014 až 2018 došlo k postupnému poklesu podílu dlouhodobých aktiv ve prospěch oběžných aktiv a z pohledu zdrojů financování postupně začaly růst cizí zdroje, jak ukazuje Tabulka 3. 
Tabulka 3: Struktura aktiv a pasiv veřejných výzkumných institucí (v mil. Kč; v \%)

\begin{tabular}{|c|c|c|c|c|c|}
\hline & $\mathbf{2 0 1 4}$ & $\mathbf{2 0 1 5}$ & $\mathbf{2 0 1 6}$ & $\mathbf{2 0 1 7}$ & $\mathbf{2 0 1 8}$ \\
\hline Bilanční suma & $\mathbf{3 3 ~ 8 8 5}$ & $\mathbf{3 7 6 1 6}$ & $\mathbf{4 2 ~ 9 0 6}$ & $\mathbf{4 6 ~ 0 5 3}$ & $\mathbf{4 8 0 6 0}$ \\
\hline Dlouhodobá aktiva (abs.) & 23895 & 27779 & 28777 & 30058 & 30569 \\
\hline Dlouhodobá aktiva (rel.) & $71 \%$ & $74 \%$ & $67 \%$ & $65 \%$ & $64 \%$ \\
\hline Oběžná aktiva (abs.) & 9990 & 9837 & 14129 & 15995 & 17491 \\
\hline Oběžná aktiva (rel.) & $29 \%$ & $26 \%$ & $33 \%$ & $35 \%$ & $36 \%$ \\
\hline Vlastní zdroje (abs.) & 31893 & 36156 & 38891 & 41576 & 43111 \\
\hline Vlastní zdroje (rel.) & $94 \%$ & $96 \%$ & $91 \%$ & $90 \%$ & $90 \%$ \\
\hline Cizí zdroje (abs.) & 1992 & 1460 & 4015 & 4477 & 4949 \\
\hline Cizí zdroje (rel.) & $6 \%$ & $4 \%$ & $9 \%$ & $10 \%$ & $10 \%$ \\
\hline
\end{tabular}

Zdroj: Vlastní zpracování na základě údajů zveřejněných v rejstř́íku VVI k 20. březnu 2020.

\section{Audit veřejných výzkumných institucí}

Následující kapitola se zabývá analýzou struktury auditorů roční účetní závěrky veřejných výzkumných institucí za roky 2014 až 2018, koncentrací těchto auditorských zakázek v rámci jednotlivých auditorů a rotací auditorů. Pro tyto účely jsou stanoveny dvě hypotézy:

Hypotéza 1: Roční účetní závěrky veřejných výzkumných institucí ověřují spíše ostatní auditorské společnosti, než auditoři osoby samostatně výdělečně činné (OSVČ) či auditorské společnosti ze skupiny tzv. ,velké čtyřky“.

Hypotéza 2: Auditorské zakázky jsou rozloženy mezi jednotlivé auditory rovnoměrně a žádný z auditorů nemá významný podíl.

Povinnost ověření účetní závěrky nezávislým auditorem vyplývá veřejným výzkumným institucím ze zákona č. 341/2005 Sb., o veřejných výzkumných institucích $\S 29$ odst. 4. Auditor je určen dozorčí radou podle zákona č. 93/2009 Sb., o auditorech $\S 17$ odst. 2: „Nemá-li účetní jednotka uvedená v odstavci 1 nejvyšší orgán, určí auditorskou společnost nebo statutárního auditora vykonávajícího auditorskou činnost vlastním jménem a na vlastní účet její kontrolní orgán, nejsou-li členové kontrolního orgánu členy řídicího orgánu. “ To uvádí také Pelák a Adamec (2018). V oblasti účetnictví postupují veřejné výzkumné instituce podle zákona o účetnictví č. 563/1991 Sb., v platném znění, vyhlášky č. 504/2002 Sb., pro účetní jednotky, u kterých hlavním předmětem činnosti není podnikání, pokud účtují v soustavě podvojného účetnictví a podle českých účetních standardů pro účetní jednotky u kterých hlavním předmětem činnosti není podnikání.

\section{Zveřejňování účetní závěrky, výroční zprávy a zprávy auditora}

$\mathrm{Na}$ základě dostupných dat lze konstatovat, že veřejné výzkumné instituce nemají se zveřejňováním účetní závěrky a zprávy auditora významné problémy. V roce 2017 i v roce 2018 nezveřejnila zprávu auditora vždy pouze 1 instituce. V roce 2014 a 2015 nezveřejnila jedna instituce př́llohu v účetní závěrce.

Podle $\S 30$ odst. 1 zákona č. 341/2005 Sb., o veřejných výzkumných institucích, musí tyto organizace povinně vypracovávat a po schválení radou instituce zveřejnit výroční zprávu, a to nejpozději do 6 měsíců po skončení kalendářního roku. Výroční zpráva se zveřejňuje uložením do sbírky listin rejstříku a zároveň prostřednictvím veřejné informací sítě. Zákon vymezuje povinné náležitosti výroční zprávy. V oblasti zveřejňování výroční zprávy nebyly identifikovány zásadní problémy. 


\section{Výrok auditora}

Pouze jedné instituci udělil auditor ve své zprávě výrok s výhradou, a to v roce 2018. Důvod spočíval $\mathrm{v}$ neprovedení inventury dlouhodobého majetku, který představoval významnou částku, a auditor tak nemohl ověřit jeho hodnotu.

\section{Odměna auditora}

Nestátní neziskové organizace, mezi něž se řadí také veřejné výzkumné instituce, mají podle vyhlášky č. 504/2002 Sb. $\S 30$ odst. 1 písm. i povinnost v př́loze v účetní závěrce zveřejnit informaci o celkové odměně přijaté auditorem za povinný audit roční účetní závěrky a celkové odměně přijaté auditorem za jiné ověřovací služby, za daňové poradenství a jiné neauditorské služby. Tato povinnost platí od 1. ledna 2016.

Pouze dvě instituce již před vznikem této povinnost informaci o odměně auditora zveřejnily, konkrétně v roce 2014 v celkové výši 95 tis. Kč. Stejně tak v roce 2015 zveřejnily odměnu auditora dvě instituce v celkové výši 70 tis. Kč. V roce 2016, kdy začala platit povinnost zveřejnění odměny auditora za povinný audit účetní závěrky, vyhovělo tomuto požadavku 55 \% institucí (odměny v celkové výši 3793 tis. Kč). V následujícím roce 2017 zveřejnilo odměnu auditora 61 \% institucí (odměny v celkové výši 3960 tis. Kč) a v roce $201867 \%$ institucí (odměny v celkové výši 4819 tis. Kč). Zároveň se ukazuje, že žádný z klientů (veřejných výzkumných institucí) některých auditorů odměny nezveřejňuje. Je patrné, že stále značná část veřejných výzkumných institucí tuto zákonnou povinnost neplní.

\section{Struktura auditorů, koncentrace auditorských zakázek, rotace auditora}

Auditory lze rozdělit do tř́ základních skupin, a to na auditory osoby samostatně výdělečně činné (OSVČ), auditorské společnosti ze skupiny tzv. Big Four (velká čtyřka zahrnující společnosti Deloitte, EY, KPMG a PwC) a ostatní auditorské společnosti. Z analýzy zpráv auditora vyplynulo, že společnosti ze skupiny tzv. Big Four se na auditu účetních závěrek veřejných výzkumných institucí nepodílejí. Tyto auditorské zakázky jsou v rukou auditorů OSVČ a ostatních auditorských společností. Strukturu auditorů v jednotlivých analyzovaných letech zachycuje Tabulka 4.

Tabulka 4: Struktura auditorů v letech 2014 až 2018

\begin{tabular}{|c|c|c|c|c|c|}
\hline & $\mathbf{2 0 1 4}$ & $\mathbf{2 0 1 5}$ & $\mathbf{2 0 1 6}$ & $\mathbf{2 0 1 7}$ & $\mathbf{2 0 1 8}$ \\
\hline OSVČ (abs.) & 15 & 12 & 11 & 9 & 8 \\
\hline OSVČ (rel.) & $20 \%$ & $16 \%$ & $15 \%$ & $12 \%$ & $11 \%$ \\
\hline $\begin{array}{c}\text { Ostatní auditorské } \\
\text { společnosti (abs.) }\end{array}$ & 59 & 62 & 64 & 65 & 66 \\
\hline $\begin{array}{c}\text { Ostatní auditorské } \\
\text { společnosti (rel.) }\end{array}$ & $80 \%$ & $84 \%$ & $85 \%$ & $87 \%$ & $88 \%$ \\
\hline Nezveřejňují (abs.) & 0 & 0 & 0 & 1 & 1 \\
\hline Nezveřejňují (rel.) & $0 \%$ & $0 \%$ & $0 \%$ & $1 \%$ & $1 \%$ \\
\hline Celkem (abs.) & $\mathbf{7 4}$ & $\mathbf{7 4}$ & $\mathbf{7 5}$ & $\mathbf{7 5}$ & $\mathbf{7 5}$ \\
\hline Celkem (rel.) & $\mathbf{1 0 0} \%$ & $\mathbf{1 0 0 \%}$ & $\mathbf{1 0 0} \%$ & $\mathbf{1 0 0} \%$ & $\mathbf{1 0 0} \%$ \\
\hline
\end{tabular}

Zdroj: Vlastní zpracování na základě zpráv auditora VVI zveřejněných v rejstř́ku VVI.

Na základě výsledků uvedených v tabulce lze potvrdit Hypotézu 1. Auditorské zakázky jsou soustředěny spíše v rukou ostatních auditorských společností než auditorů OSVČ. Podíl ostatních auditorských společností v čase neustále rostl.

Z analýzy zpráv auditorů za sledované období let 2014 až 2018 plyne, že roste podíl jedné auditorské společnosti na celkovém počtu auditovaných účetních závěrek veřejných 
výzkumných institucí. O tom svědčí níže uvedená Tabulka 5. Ostatní auditorské společnosti a auditoři OSVČ z hlediska zakázek nezaujímají jednotlivě ani $10 \%$ podíl. Rozložení těchto ostatních auditních zakázek se tedy zdá být vcelku rovnoměrné.

Tabulka 5: Koncentrace auditorských zakázek v letech 2014 až 2018

\begin{tabular}{|c|c|c|c|c|c|}
\hline & $\mathbf{2 0 1 4}$ & $\mathbf{2 0 1 5}$ & $\mathbf{2 0 1 6}$ & $\mathbf{2 0 1 7}$ & $\mathbf{2 0 1 8}$ \\
\hline Diligens, s. r. o. (abs.) & 16 & 17 & 16 & 18 & 22 \\
\hline Diligens, s. r. o. (rel.) & $22 \%$ & $23 \%$ & $21 \%$ & $24 \%$ & $29 \%$ \\
\hline
\end{tabular}

Zdroj: Vlastní zpracování na základě zpráv auditora VVI zveřejněných v rejstř́íku VVI.

Hypotézu 2 nelze potvrdit, jelikož jedna z auditorských společností zaujímá oproti ostatním auditorským společnostem a auditorům OSVČ značný podíl, který zejména v posledním sledovaném roce narostl. Existuje zde riziko, že i další veřejné výzkumné instituce, resp. jejich dozorčí rady v budoucnu určí svým auditorem auditorskou společnost Diligens, s. r. o. a její podíl opět posílí. Z hlediska nezávislosti auditora na auditované účetní jednotce je vhodnější, aby byly zakázky roztřišstěné mezi více auditorů a nesoustředily se u několika málo auditorů. Ve světě se uplatňuje např. povinná rotace auditorů, losování či ověřování účetní závěrky dvěma nezávislými auditory.

\section{Rotace auditora}

Převážná část institucí během sledovaného období nezměnila svého statutárního auditora. Ty, které jej změnily, tak jednou či dvakrát, což naznačuje Tabulka 6 .

Tabulka 6: Rotace auditorů v letech 2014 až 2018

\begin{tabular}{|c|c|c|}
\hline & Absolutně & Relativně \\
\hline Beze změny & 40 & $53 \%$ \\
\hline Změna jednou & 29 & $39 \%$ \\
\hline Změna dvakrát & 6 & $8 \%$ \\
\hline
\end{tabular}

Zdroj: Vlastní zpracování na základě zpráv auditora VVI zveřejněných v rejstříku VVI.

Nejčastěji došlo ke změně auditora způsobem přechodu mezi auditorskými společnostmi, mnohem méně pak přechodem mezi osobami samostatně výdělečně činnými a přechodem od osob samostatně výdělečně činných k auditorským společnostem. Uvedené vyplývá z Tabulky 7.

Tabulka 7: Změny auditora v letech 2014 až 2018

\begin{tabular}{|c|c|c|}
\hline & Absolutně & Relativně \\
\hline Přechod mezi OSVČ & 2 & $6 \%$ \\
\hline Přechod mezi auditorskými společnostmi & 26 & $74 \%$ \\
\hline Přechod od OSVČ k auditorské společnosti & 7 & $20 \%$ \\
\hline
\end{tabular}

Zdroj: Vlastní zpracování na základě zpráv auditora VVI zveřejněných v rejstř́íku VVI.

\section{Závěr}

Veřejné výzkumné instituce vesměs zveřejňují účetní závěrky, výroční zprávy a zprávy auditora. Stejně tak téměř všechny obdržely od svého auditora výrok bez výhrad.

Naopak značná část institucí nedodržuje povinnost zveřejnit odměnu auditora $\mathrm{v}$ př́loze $\mathrm{v}$ účetní závěrce. 
Auditorem účetní závěrky těchto neziskových organizací jsou převážně ostatní auditorské společnosti, mnohem méně pak auditoři OSVČ. Auditorské společnosti z „velké čtyřky“ se na těchto zakázkách nepodílejí. Obdobný trend lze vidět i u nadací a politických stran a hnutí, jak naznačují citované výzkumy. Tento závěr lze pravděpodobně vztáhnout na celý český neziskový sektor.

U veřejných výzkumných institucí se projevuje rostoucí koncentrace těchto auditních zakázek $\mathrm{v}$ rámci jedné auditorské společnosti (oproti jiným neziskovým organizacím zmíněným v citovaných výzkumech) a je otázkou, jaký bude budoucí vývoj. Z hlediska nezávislosti jde spíše o negativní skutečnost.

Více než polovina sledovaných institucí nezměnila $\mathrm{v}$ analyzovaném období svého auditora. Pokud však ke změně došlo, tak spíše jednou, max. dvakrát.

Změna se uskutečnila nejčastěji (v $74 \%$ př́padů) přechodem mezi auditorskými společnostmi, což koresponduje se strukturou auditorů, konkrétně se zjištěním, že převážná část těchto auditních zakázek připadá na ostatní auditorské společnosti.

S ohledem na účetní předpoklad „going concern“ vykazovala v průběhu celého sledovaného období jedna instituce záporné vlastní zdroje. V období let 2014 až 2016 se k ní přidala ještě jedna další instituce. Na tuto skutečnost by měl auditor upozornit ve své zprávě v závislosti na tom, zda ji účetní jednotka řádné popsala v př́loze v účetní závěrce. Pokud ano, upozorní auditor na příslušný bod přílohy účetní závěrky ve své zprávě, aniž by modifikoval výrok. V opačném př́ipadě, kdy účetní jednotka tuto skutečnost dostatečně nevysvětluje a nepopisuje v př́loze v účetní závěrce, může auditor udělit záporný výrok. Obvykle jde o existenci významné (materiální) nejistoty, která může zásadním způsobem zpochybnit schopnost účetní jednotky nepřetržitě trvat.

\section{Poděkování}

Tento článek vznikl $\mathrm{v}$ rámci institucionální podpory na dlouhodobý koncepční rozvoj výzkumu, vývoje a inovací č. IP100040 na Fakultě financí a účetnictví Vysoké školy ekonomické v Praze.

\section{Literatura}

[1] BACHMANN, P., 2012. Transparentnost organizaci občanské společnosti. Hradec Králové: Gaudeamus. ISBN 978-80-7435-235-5.

[2] BEHN, B. K., D. D. DEVRIES and J. LIN, 2010. The determinants of transparency in nonprofit organizations: An exploratory study. Advances in Accounting. Vol. 26, Issue 1, p. 6-12. ISSN 0882-6110.

[3] BROWN, H. and D. RUHL, 2003. Breakthrough management for Not-for-Profit Organizations: Beyond survival in the 21st Century. Praeger. ISBN 1-56720-639-5.

[4] JOŠT, M., 2016. Transparentnost hospodaření př́jemců př́spěvkì z Nadačního investičního fondu. Český finanční a účetní časopis, roč. 11, č. 2, s. 93-108. ISSN 18022200.

[5] JOŠT, M., 2016. Zveřejňování informaci českými nadacemi voblasti auditu. In: Recenzovaný sborník př́spěvků mezinárodní vědecké konference, 12. - 16. prosince 2016, Mezinárodní Masarykova konference pro doktorandy a mladé vědecké pracovníky, ročník VII. MAGNANIMITAS: Hradec Králové. ISBN 978-80-87952-17-7. 
[6] JOŠT, M., 2017. Transparentnost hospodaření českých nadací. Disertační práce. Vysoká škola ekonomická v Praze.

[7] JOŠT, M., 2018. Audit politických stran a politických hnutí vpodmínkách České republiky. In: Recenzovaný sborník příspěvků vědecké interdisciplinární mezinárodní vědecké konference doktorandů a odborných asistentů, 27. - 29. června 2018, QUAERE 2018. MAGNANIMITAS: Hradec Králové. ISBN 978-80-87952-26-9.

[8] KAČR, 2019. Auditor, č. 10, ročník XXVI. Metodická pomůcka k poskytování auditorských služeb u nestátních nevýdělečných organizací dle stavu legislativy k 30. listopadu 2019. ISSN 1210-9096.

[9] KAČR, 2020. Mezinárodní auditorské standardy přijaté KA ČR (vydání 2018) [online]. [vid. 16. května 2020]. Dostupné z: https://www.kacr.cz/aktualni-auditorske-standardy

[10] LÉROVÁ, A, 2015. Politické strany a politická hnutí. Auditor, č. 6, roč. XXII. ISSN 1210-9096.

[11] PELÁK, J. a J. ADAMEC, 2018. Určení auditora u nestátních neziskových organizací. Auditor, č. 1, roč. XXV. ISSN 1210-9096.

[12] POSPÍŠIL, M., 2006. Jak zahájit debatu o transparentnosti? Brno: Centrum pro výzkum neziskového sektoru [online]. 8. srpna 2006 [vid. 16. května 2020]. Dostupné z: http://www.e-cvns.cz/?typ=konferencni_prispevky\&publikace=71\&presenter=Publikace

[13] PUTNAM, R., 1993. Making Democracy Work. Princeton: Princeton University Press. In: SARGEANT, A. Marketing Management for Nonprofit Organizations. New York: Oxford University Press. ISBN 0-19-927182-8.

[14] SALAMON, L. M. and H. K. ANHEIER, 1996. The International Classification of Nonprofit Organizations: ICNPO-Revision 1. Baltimore: The Johns Hopkins University, Institute for Policy Studies. ISBN 1-886333-23-8.

[15] ŠEDIVÝ, M. a O. MEDLÍKOVÁ, 2011. Úspěšná nezisková organizace. Grada Publishing. ISBN 978-80-247-4041-6. 